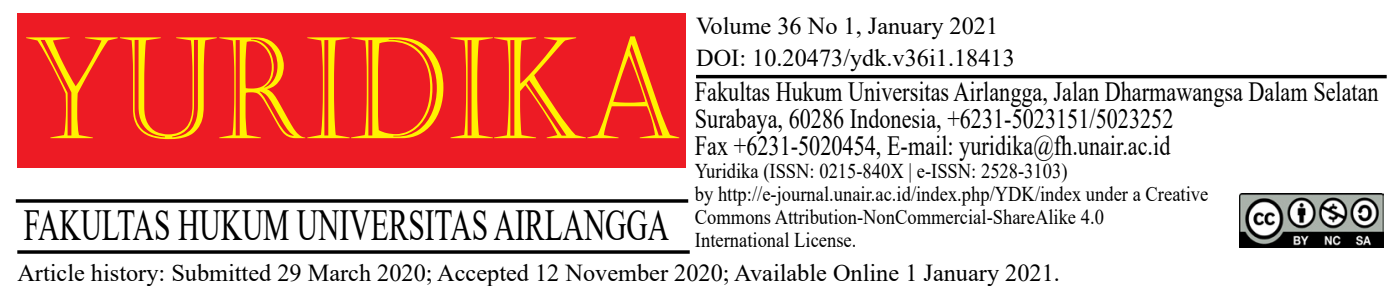

\title{
Analysis on the Legal Force of Copyright Registration Document as Evidence of Ownership of Indigenous Land
}

\author{
Christina Ella Yonatan and Xavier Nugraha \\ cellayonatan@yahoo.com \\ Notary Public and Land Deed Notary Office Christina Ella Yonatan
}

\begin{abstract}
Registration of copyright patent or registration is a letter approved and issued by the Ministry of Law and Human Rights for copyright. To protect the rights to indigenous land, the Moi tribal community has registered 2 (two) registrations that have been issued by the Ministry of Law and Human Rights, including 1) Registration of copyright with types of creation: Database and title of work: Results of the Open and Close Tribe Meeting with the head of the Tribe Council of Malamoi Sorong and Indigenous Peoples of the Moi Tribe on the Status of Indigenous Land Ownership in the Sorong City Government Area on behalf of the Malibela Klawalu clan, the Kalagison Milo clan, the Mubalus clan, the Kalawaisa clan, the Bawela Mubalus clan, the Osok Malaimsimsa clan. Marga Kalami Klaglas Klaglas On 10 April 2013. 2). Letter of Registration of copyright with the type of copyrights: Map of the 7 Boundary of the Moi Indigenous Land Owners in the Sorong City Area. Based on the document, the Moi tribal community used it as a basis to claim the lands in the Sorong City government territory were the indigenous land belonging to the Moi tribe. This study uses a statutory and conceptual approach. The results of this study are that the registration document does not have legal force as evidence to prove ownership of indigenous land rights. A letter of registration remains important if there are legal issues with copyright in the future.
\end{abstract}

Keywords: Registration of Copyright Document; Right of Ownership; Indigenous Land.

\section{Introduction}

Copyright is a type of Intellectual Property Rights. Copyright is defined according to Article 1 paragraph (1) of Law Number 28 Year 2014 concerning Copyright (hereinafter referred to as Law 28/2014) is the exclusive right of the creator/inventor which arises automatically based on the declarative principle after creation or work is realized in tangible form without reducing restrictions by the 
provisions of the legislation. Copyright automatically means that the copyright adheres to the first to use/declarative system not first to file. ${ }^{1}$ Thus, the registration of a work is not an obligation for the creator or copyright holder in Indonesia.

This declarative registration gives the creator exclusive rights to be able to prohibit other parties from announcing and reproducing the work. ${ }^{2}$ In exclusive rights, there are two essential rights, namely economic rights and moral rights. ${ }^{3}$ Although the copyright legal regime provides protection when the work is realized/ announced, the registration of copyright is still carried out in Law 28/2014 as a protection for the copyright holders themselves.

In accordance with Article $64 \mathrm{X}$ of Law 28/2014, registration of copyright is carried out by the Directorate General of Intellectual Property (DJKI), which is now under the Ministry of Law and Human Rights. To date, 180.024 applications for copyright registration have been filed. ${ }^{4}$ According to Article 69 paragraph (1) of Law $28 / 2014$, if the application for registration is accepted, a letter of registration of the work will be issued and recorded in the general register of the copyright. Therefore, a Registration of copyright is a document that has been approved and issued by the Ministry of Law and Human Rights for copyrights which contain the name of the Author and the Copyright Holder or the name of the owner of the Related Right product. Based on Article 66 paragraph (1) of Law 28/2014, the creator or copyright holder can register his work directly or by appointing a representative (Intellectual Property Consultant).

The need for copyright provides a solid regulatory basis for its implementation, bearing in mind that the copyright law system has been fully developed, it is not necessary to practice violations in various fields of copyright

\footnotetext{
1 Sudjana, 'Sistem Perlindungan Atas Ciptaan Berdasarkan Undang-Undang Nomor 28 Tahun 2014 Tentang Hak Cipta Dalam Perspektif Cyber Law' (2016) 2 Veritas et Justitia.[266].

2 Siti Hatikasari, 'Esensi Perlindungan Hukum Dalam Sistem First to Announce Atas Karya Cipta’ (2018) 27 Supremasi Hukum: Jurnal Penelitian Hukum.[120].

3 Sthephen M. McJohn, Copyright, Examples \& Explanation (Aspen Publisher 2006).[62].

4 Direktorat Jenderal Kekayaan Intelektual, 'Pangkalan Data Kekayaan Intelektual' (Direktorat Jenderal Kekayaan Intelektual, 2018) <https://pdki-indonesia.dgip.go.id/index.php/hakcipta?type $=2 \& q 14[$ from $]=01-03-2019 \& q 14[$ until $]=23-03-2020 \&$ filter_by=dicatat $>$ accessed 23 March 2020.
} 
both in violation of economic rights and moral rights. ${ }^{5}$ However, the reality is the registration of the work is not fully able to protect the economic rights and moral rights of the creator. Based on Article 1 number 2 jo. Article 31 of Law $28 / 2014$, which is defined as the creator does not rule out the possibility that one of them is an indigenous community. Based on Ter Haar's opinion, what is meant by indigenous law is a structured group of humans, settling in certain areas, having tangible or intangible rulers and wealth, whose members experience such social life as natural and have no tendency to disperse/break away from their boundary. ${ }^{6}$ The existence of this indigenous community was also recognized in Article 18B paragraph (2) of the 1945 Constitution of the Republic of Indonesia. One of the indigenous peoples who felt disadvantaged was the indigenous people of Moi Tribe who registered the boundary map as their creation. The Moi tribal community uses the evidence of the registration of copyright as evidence to claim a land is owned by the Moi tribal community.

Currently, there are 2 (two) registration documents of work issued by the Ministry of Law and Human Rights that are used by indigenous peoples of Moi as a basis for claiming lands in the Sorong City government territory are indigenous lands belonging to the Moi tribe, although the lands are within the area of Sorong City is the former erfpacht land that already has a legal and strongest proof of land ownership certificate in Indonesia. The registration of the work owned by the indigenous tribe community results in the manipulation by the indigenous community on the assets of the BUMN (State-Owned Business), based on 2 (two) registration documents of work issued by the Ministry of Law and Human Rights, including:

1. Registration of copyright with the type of creation: Database and title of creation: Results of Open and Closed Tribe Meeting with the Chairperson of Indigenous Council of Malamoi Sorong and Indigenous People of Moi Tribe Regarding

\footnotetext{
5 Henry Soelistyo, Hak Cipta Tanpa Hak Moral (Rajawali Pers 2011).[86].

6 Mochamad Adib Zain and Ahmad Siddiq, 'Pengakuan Atas Kedudukan Dan Keberadaan Masyarakat Hukum Adat (MHA) Pasca Dibentuknya Undang-Undang Nomor 6 Tahun 2014 Tentang Desa' (2015) 2 Jurnal Penelitian Hukum.[66].
} 
the Status of Indigenous Land Ownership in Sorong City Government Area of Malibela Klawalu Clan, Kalagison Milo clan, Mubalus clan, Kalawaisa clan, Bawela Mubalus clan, Osok Malaimsimsa clan, Kalami Klaglas Klakalud clan on 10 April 2013, Registration Number: 000123503.

2. Registration of Copyright with the type of work: Map and title of work: Map of the 7 Borders of the Moi Tribal Indigenous Land Ownership in Sorong City Area, Registration Number: 000123502.

At the moment the document is used by indigenous peoples to claim most of the land in the Sorong City area as indigenous land, where threats have been made to BUMN (State-Owned Business) assets such as Bank Mandiri, BNI, BRI, Bank Danamon and several places in Sorong City. Because 2 (two) registrations of the work caused chaos in the Sorong City Region, the Director of Copyright and Industrial Design issued an explanatory note related to the recording of the work, the contents of which said work cannot be used as a basis for proof of ownership of the legal status of land rights given that it is related the ownership status of the land rights is a different legal domain from the copyright.

Another legal domain in question is the land law. True land law is part of agrarian law. ${ }^{7}$ The land is governed by the state constitutionally in Article 33 paragraph (3) of the 1945 Constitution that "The earth, water and natural resources contained therein are controlled by the state and used for the greatest prosperity of the people". The provisions of this article later became a philosophical basis for land arrangements in Indonesia which were legally regulated in Law Number 5 of 1960 concerning Basic Agrarian Regulations which came to be known as the Basic Agrarian Law (UUPA).

The land which is the object of the problems of the Moi tribe is the indigenous land. In general, Imam Sudiyat believes that ulayat land can be interpreted as the land of a certain indigenous tribe community. ${ }^{8}$ According to Boedi Harsono, ulayat

7 Urip Santoso, 'Kewenangan Pemerintah Daerah Dalam Penguasaan Atas Tanah' (2013) 27 Jurnal Mimbar Hukum.[99].

8 Bzn. Ter Haar, Asas-Asas Dan Susunan Hukum Adat (Pradnya Parata 1999).[63]. 
land is shared land, which is believed to be the legacy of ancestors or the gift of supernatural powers to the indigenous tribe/community as the main support for the life of the tribe forever. ${ }^{9}$ The definition of ulayat land is not defined in the UUPA, but the UUPA( Basic Agrarian Law) recognizes the existence of ulayat land with ulayat rights. Based on Article 3 of the UUPA (Basic Agrarian Law), indigenous rights or indigenous land rights are recognized, but the recognition is followed by conditions that must be fulfilled, including their existence, not in conflict with national interests and not in conflict with the rules of the Law. The recognition of indigenous rights under the terms of the UUPA (Basic Agrarian Law) tends not to provide legal certainty in implementation, because the regulation is vague and indecisive. ${ }^{10}$ In the absence of full recognition of indigenous community land, land disputes between indigenous law communities and other groups originating from still occur. The Supreme Court statistics show that 14 indigenous land/disputes were terminated in $2017 . .^{11}$

Land for human life contains multidimensional meaning. First, in terms of economic land is a means of production that can bring prosperity, Second, politically the land can determine the position/someone or rights in decision making, Third, as a cultural capital can determine the level of the social status of the owner, Fourth, the land may have the sacred meaning as at the end of life everyone will return to the land(buried). ${ }^{12}$ As a result of this multi-dimensional meaning, there is a tendency that people who own land will defend their land in any way if their rights are violated, oh how meaningful a land is for human life and for a country. Meanwhile, the meaning of land for indigenous and tribal peoples is as a geographical and social entity that is inhabited from generation to generation, inhabited, controlled,

9 Andi Bustamin Daeng Kunu, 'Kedudukan Hak Ulayat Masyarakat Adat Dalam Hukum Tanah Nasional' (2010) 10 Inspirasi.[45].

${ }^{10}$ Rosalina, 'Eksistensi Hak Ulayat Di Indonesia' (2010) 16 Jurnal Sasi.[50].

11 Direktorat Jenderal Badan Peradilan Umum, 'Statistik Perkara Perdata Klasifikasi Objek Sengketa Tanah Tahun 2017' (Direktorat Jenderal Badan Peradilan Umum, 2017) <https://badilum. mahkamahagung.go.id/publik/statistik-perkara/statistik-perkara-perdata/2512-statistik-perkara-perdata-klasifikasi-objek-sengketa-tanah-tahun-2017.html> accessed 23 March 2020.

${ }^{12}$ Heru Nugroho, 'Menggugat Kekuasaan Negara', Muhamadyah University Press (2001).[237]. 
and managed by indigenous peoples, both as a source livelihood, as well as social identity markers inherited by their ancestors. ${ }^{13}$

The Moi land ownership rights are communal, but in the case of the use of the land, it can be used both communally and individually. There is no obligation to control, and use it collectively, as the use of land is essential to meet the needs of individuals and their families. The group's needs can be met by utilizing the land for livestock grazing, markets, and settlements, which referred to as iik fagu. The trust in the living relationship between the Moi people is related to each other and the land where they live. Land is a place where they look for food, when they die, they will be buried there and will become the residence of their ancestors, as well as a place to live for their children and grandchildren.

On the other hand, the meaning of land in the life of the Moi tribe is very sacred, because there is an assumption that land is the mother of the Moi tribe so that it means that if selling land is the same as selling their mother. Ownership of indigenous land rights is also hereditary. This means that the rights to manage and own the land are inherited in a clan lineage within the tribe, while for administrative matters and the inventory of these indigenous lands, the Moi tribe has an institution, which until now has been recognized and has its existence both in the community itself as well as in the concept of sovereign governance.

If the land referred to in the boundary map is indigenous land, then the indigenous rights to the land of Moi follows over the land. These indigenous rights contain authority to: ${ }^{14}$

a. Manage and administer land use (such as plantation use, settlement, etc.), land maintenance, inventory (such as making rice fields / new settlements, etc.);

b. Regulate and determine legal relations between people and land (such as giving certain rights to certain legal subjects); as well as

\footnotetext{
${ }^{13}$ Ahyat Ari Gayo, 'Perlindungan Hukum Ha Katas Tanah Adat (Studi Kasus Di Provinsi Aceh Khususnya Kabupaten Bener Meriah)' (2016) 18 Jurnal Penelitian Hukum De Jure.[291].

${ }^{14}$ Maria S.W. Sumardjono,[et., al.], Kebijakan Pertanahan Antara Regulasi \& Implementasi (Kompas 2001).[53].
} 
c. Regulate and establish legal relations between people and legal actions relating to the land (such as inheritance, sale, and so on).

Thus, the Moi tribal people are given the right to regulate and establish legal relations between people and legal actions relating to the land, including the use of land for BUMN (State-owned business) assets.

The UUPA (Basic Agrarian Law)does regulate limited recognition of indigenous rights, but so far no complete information has been provided about the extent and boundaries of indigenous land territories as well as proof of indigenous community rights. ${ }^{15}$ With the limitation of the indigenous land solid evidence, the Moi indigenous people used the Moi indigenous land registration document to claim the majority of the land in the Sorong City area as indigenous land. However, the position of this boundary map creation document needs to be reviewed to answer the problem of proving disputed land ownership.

With the absence of proof of ownership from the indigenous communityy, the appropriateness of the use of the registration of copyright document to be used as proof of ownership of indigenous people become the main problem that needs to be examined. Based on this background, this article will discuss the legal issues as the legal status of registration of copyright document regarding boundary maps and results of open and closed tribe meetings of the tribe council and the legal force of the registration of a work as evidence to prove ownership of indigenous land rights.

The article is a legal article. Peter Mahmud Marzuki stated that legal article was carried out to find legal rules, legal principles, and legal doctrines to address the legal issues in question. ${ }^{16}$ This is actually in accordance with the character of legal science which is prescriptive. ${ }^{17}$ This legal article was carried out to determine the

\footnotetext{
15 Hayatul Ismi, 'Pengakuan Dan Perlindungan Hukum Hak Masyarakat Adat Atas Tanah Ulayat Dalam Upaya Pembaharuan Hukum Nasional' (2012) 3 Jurnal Ilmu Hukum Fakultas Hukum Universitas Riau.[8].

${ }_{16}$ Peter Mahmud Marzuki, Penelitian Hukum (Prenada Media Group 2005).[35].

17 Titik Triwulan Tutik, 'Hakikat Keilmuan Ilmu Hukum Ditinjau Dari Sudut Filsafat Ilmu Dan Teori Hukum' (2012) 24 Mimbar Hukum.[456].
} 
legal standing of the legal status of the registration of copyright which was used as the basis for evidence of ownership of indigenous land rights.

Legal article should require certain methods of approach to obtain information from various aspects to address legal issues as article objects. ${ }^{18}$ Generally, the methods used in legal article to address certain legal issues are statute approach, case approach, historical approach, comparative approach, and conceptual approach. ${ }^{19}$ In this study, the approach used to answer legal issues related to it is the statute approach and conceptual approach.

The statute approach is carried out by reviewing all laws and regulations relating to the legal issues being handled. ${ }^{20}$ The statutory approach is used with the aim of studying the consistency and compatibility between laws and regulations. In using the statute approach, articleers do not only look at the form of legislation but also examine the material content including the ontological basis, the philosophical basis of the law and the ratio legis of the provisions of the law with the aim to find out whether there is a philosophical conflict between the law and the issue in question. ${ }^{21}$ Some of the laws and regulations used are those relating to the registration of copyright documents that are used as the basis for evidence of ownership of indigenous land rights, including:

1. Law Number 5 of 1960 concerning Basic Regulations on Agrarian Principles (State Gazette of 1960 Number 104, Supplement to State Gazette Number 2043);

2. Law Number 21 of 2001 concerning Special Autonomy for the Province of Papua (State Gazette of the Republic of Indonesia of 2001 Number 135, Supplement to the State Gazette of the Republic of Indonesia Number 4151);

3. Law Number 35 of 2008 concerning the Stipulation of Government Regulation in Law Number 1 of 2008 concerning Amendment to Law Number 21 of 2001 concerning Special Autonomy for the Province of Papua (State Gazette of the Republic of Indonesia of 2008 Number 112, Supplement to the State Gazette Republic of Indonesia Number 4884);

4. Law Number 28 of 2014 concerning Copyright (State Gazette of the Republic

\footnotetext{
18 Xavier Nugraha, [et.,al.] 'Rekonstruksi Batas Usia Minimal PerkawinanSebagai Bentuk Perlindungan Hukum TerhadapPerempuan’ (2019) 3 Lex Scentia.[43].

19 Peter Mahmud Marzuki (n 16).[93].

${ }^{20}$ ibid.[133].

21 ibid.
} 
of Indonesia of 2014 Number 266, Supplement to the State Gazette of the Republic of Indonesia Number 5599);

5. Government Regulation No. 24/1997 concerning Land Registration (State Gazette No. 59/1997, State Gazette No. 3696).

The conceptual approach moves from the views and doctrines that develop in the science of law. ${ }^{22}$ By studying the views and doctrines, ideas that lead to legal notions, legal concepts and legal principles that are relevant to the legal issues in question. The concept used in this study is related to the registration of the copyright document which is used as the basis for proof of ownership of indigenous land rights.

\section{Legal status of Registration of Copyright Certificate concerning Boundary Maps and Results of Open and Close Indigenous tribe Meeting Sessions of the Indigenous Council.}

Dedy Miswar stated that the map is a conventional description of the earth's surface being reduced in scale as seen when viewed from above with the added writings as identification. ${ }^{23}$ The function of the map is to draw or systematically record the location of the earth's surface data, both physical and cultural data that have been previously determined. ${ }^{24}$ Thus, maps are useful for demonstration, reporting, analysis, and understanding of spatial relationships. Next, the map user will use the map as a pointer to show the appearance of the earth's surface, area, distance, and other purposes according to the information contained in the map.

Boundaries in the Great Indonesian Dictionary are interpreted as dividing lines (between administrative units or between different geographical regional units, both cultural and physical). ${ }^{25}$ Thus, a boundary map is a map that contains boundaries or dividers (between administrative units or between different geographical regional units, both physical and cultural), describing the borders of a country or region.

\footnotetext{
${ }^{22}$ ibid.[135].

${ }^{23}$ Dedy Miswar, Kartografi Tematik, vol Aura (Aura 2012).

24 ibid.[15].

25 Ebta Setiawan, 'KBBI Online' $(K B B I, 2019)<$ https://kbbi.web.id/tapal-3> accessed 24 March 2020.
} 
The making of the boundary map itself is one form of implementation of indigenous rights owned by the indigenous people of the Moi tribe. Maria Sumardjono, provide a certain criterion to determine the existence of indigenous rights based on the presence of three elements that must be met cumulatively, namely:

1. The subject of indigenous rights, namely indigenous law communities with certain characteristics. The decision of the Constitutional Court Number 31/ PUU/2007 has established characteristics to assess the existence of indigenous and tribal people, namely: ${ }^{26}$

a. Currently or Still alive, in the sense that there are people who have group feelings, indigenous government institutions, indigenous assets, indigenous legal norms, and exist in certain areas;

b. In accordance with community development, in the sense that the substance of traditional rights is recognized and acknowledged by the indigenous community itself and the wider community;

c. In accordance with the principles of the Unitary State of the Republic of Indonesia, in the sense that its existence does not threaten sovereignty and integrity and does not conflict with applicable laws and regulations;

d. Regulated in law, such as recognition of indigenous and tribal peoples in the Basic Agrarian Law.

2. The existence of indigenous rights objects, namely land located within an area and is the main supporter of the livelihood and life of the people;

3. The authority of indigenous and tribal peoples to take certain actions.

The Moi tribal community itself has already fulfilled the three elements above and is an indigenous community in Papua that has been recognized as having indigenous rights to administer land in its indigenous legal system. ${ }^{27}$ This indigenous law is used to divide the indigenous land area to the clans in the Moi tribe. ${ }^{28}$ Although the boundaries of the land ownership areas are not marked with

\footnotetext{
26 Maria Sumardjono,[et.,al.], Mediasi Sengketa Tanah (Potensi Penerapan Alternatif), Penyelesaian Sengketa Di Bidang Pertanahan) (Kompas Media 2008).[231].

27 Yulianan A and Heriyanti, 'Model Partisipasi Masyarakat Moi Dalam Pelaksanaan Pendidikan Adat Kambik (Studi Kasus Tentang Kelangsungan Pendidikan Kambik Di Suku Moi Kampung Maladofok Kabupaten Sorong)' (2019) 4 Jurnal Noken.[75].

${ }^{28}$ Hermanto Suaib, Nilai-Nilai Kearifan Lokal Dan Modal Sosial Dalam Pemberdayaan Masyarakat Suku MOI (Penerbit Book Online 2017).[75].
} 
pillars as in-state land certification, the Moi community is very obedient to the boundary markers with various natural objects, such as wood trees, rivers, rocks, mountains and so on.

All of the clans in the Moi tribe already know the boundaries of their land, thus they will not carelessly enter other hamlets or clan lands. Each clan usually has its sacred territory or property for ownership of the land. ${ }^{29}$ The mapping of indigenous territories is important as a strategy against the seizure of indigenous territories. ${ }^{30}$ Even though the Regulation of the District of Sorong No.10 of 2017 regarding Recognition and Protection of the Moi Indigenous Law Community in Sorong Regency has existed, the seizure of indigenous territories is still ongoing. Therefore, a clan map of boundaries is important to be realized.

To prevent conflicts, the Moi indigenous people conduct participatory mapping of their indigenous territories. Now the mapping is complete. After the traditional ratification, the community hopes that the Sorong City Government and Sorong Regency can recognize the area and the Sorong City Government and Sorong Regency can issue regional regulations or regent decrees that recognize and protect the Malamoi indigenous people along with their indigenous rights and territories.

The participatory mapping was also based on the results of the open and closed indigenous session of the tribe council of the Malamoi Sorong region and the Moi tribal people regarding the status of indigenous land ownership. An indigenous tribe council is a governmental institution of an indigenous law community at the provincial, district, city and community level. The Indigenous Council must be seen as an institution that has been implicitly backed up in its formation by the Special Autonomy Law (of Papua). Indigenous councils need to be given space or authority to play their role as Indigenous People Organization.

\footnotetext{
${ }^{29}$ ibid.

30 Eka Hindrati, 'Melawan Perampasan Wilayah Adat Dengan Peta Wilayah Adat' (aman, $2015)<$ http://www.aman.or.id/2019/05/melawan-perampasan-wilayah-adat-dengan-peta- wilayahadat $>$ accessed 26 February 2020.
} 
Since the indigenous council is a representation of an indigenous community, the indigenous council must come from the region through the correct democratic mechanism, namely the Tribe meeting or Conference, ${ }^{31}$ not for unilateral claims for the sake of personal or group interests. Copyright registration is carried out by the indigenous people of Moi not only for the object of the boundary map, but also for the object of the results of the tribe assembly regarding the ownership of their indigenous land.

The copyright registration document that comes out after is included in the protection of intellectual property rights. In intellectual property rights, there are three connected elements, namely: ${ }^{32}$

a. There are exclusive rights granted by law to right holders;

b. The right concerns human effort based on intellectual ability;

c. Intellectual ability has economic value.

Thus, it appears that the domain of Intellectual Property Rights (IPR) is both a protection and an award for the creator who has devoted their intellectual ability to create a work.

The award for the existence of the copyrighted work is in the form of granting exclusive rights which include economic and moral rights. Economic rights are the rights to obtain economic benefits for HKL/IPR(Intellectual Property Right), in other words obtaining IPR recognition in the form of granting permits or using copyrighted works by obtaining royalties. ${ }^{33}$ While moral rights are rights inherent to the creator that cannot be erased for any reason even though they have been transferred..$^{34}$

In general, intellectual property protection recognizes two registration systems, namely: the first to use/declarative system and the first to file/constitutive

31 Nelwan Ronsumbre and Mohammad Benny, 'Keberadaan Perwakilan Wilayah Adat Di Dewan Perwakilan Rakyat Papua (DPRP) Dalam Perspektif Representasi Di Provinsi Papua' (2018) 1 Responsive.[68].

${ }^{32}$ Tomy Suryo Utama, Hak Kekayaan Intelektual (HKI) Di Era Global (Graha Ilmu 2010).[2].

${ }_{33}$ Iswi Hariyani, Prosedur Mengurus HKI Yang Benar (Pustaka Yustisia 2010).[61].

${ }^{34}$ Ermansyah Djaja, Hukum Hak Kekayaan Intelektual (Sinar Grafika 2009).[115]. 
system. A first to use registration system means that protection is born due to the announcement or use of intellectual property, while a first to file registration system means that protection is issued due to registration. ${ }^{35}$ The status of the registration document is merely declarative, meaning that it only confirms the copyright that has been issued since the creation came into being. Thus, registering a copyright is not an obligation, but a right. Thus, the decision to register the copyright for the work that has been made entirely rests within the hand of the individual, group, or institution that created it. ${ }^{36}$ The output of the work that has been registered is a letter of registration of copyright documents.

Although it is not a mark of issuance or protection of a work, the function copyright document provides the initial suspicion that someone who registers the work can be called the creator, until there is another party who can prove otherwise. ${ }^{37}$ Thus, the record has a protection function against unauthorized use or without the author's permission. In other words, when copyright has been registered in advance, there is no need for the worry of others who can sabotage and take advantage of a painstakingly constructed work. ${ }^{38}$ If there is a dispute in court regarding a registered work, the judge can determine the actual creator from the initial evidence in the form of a written registration of the copyright/work. ${ }^{39}$ So, if other people intend to claim the work that has been registered, then that other person is obliged to prove. This is under the legal principle "whoever postulates, must prove it" ${ }^{40}$

Besides the protection function, the benefits of registering copyright are economic functions. If other parties want to use a trademark that has registered

${ }^{35}$ Sufiarina, 'Hak Prioritas Dan Hak Ekslusif Dalam Perlindungan HKI' (2013) 3 ADIL:Jurnal Hukum.[274].

${ }^{36}$ Bplawyers, 'Hak Cipta: Mengenal Lebih Dalam Hak Cipta Di Indonesia' (Bplawyers, $2018)<$ https://bplawyers.co.id/2018/01/30/hak-cipta-di-indonesia/> accessed 26 February 2020.

${ }^{37}$ Inda Nurdahniar, 'Analisis Penerapan Prinsip Perlindungan Langsung Dalam Penyelenggaraan Pencatatan Ciptaan’ (2016) 2 Veritas et Justitia.[248].

${ }^{38}$ Trias Palupi Kurnianingrum, 'Materi Baru Dalam Undang-Undang Nomor 28 Tahun 2014 Tentang Hak Cipta’ (2015) 6 Jurnal Negara Hukum.[95].

39 Siti Hatikasari (n 2).[125].

${ }^{40}$ Maria Rosalina, 'Pengaturan Pemeriksaan Setempat (Decentee) Dalam Peraturan Perundang-Undangan Di Indonesia' (2018) 18 Jurnal Hukum Kaidah <https://jurnal.uisu.ac.id/ index.php/jhk/article/view/909>. [2]. 
copyright or trade for certain interests such as marketing, then the party must first ask permission from the creator. The creator also has the authority to refuse or accept certain cooperation such as the existence of some money to be paid or so on.

Based on Article 40 paragraph (1) letter i of Law 28/2014, the boundary map is included in the protected work. The boundary map is indeed included in the definition of a work contained in Article 1 number 3 28/2014 which states that a work is "every copyrighted work in the fields of science, art, and literature that results from inspiration, ability, thought, imagination, dexterity, skills, or expertise expressed in tangible form. "A new work obtain protection when it has been realized as a tangible creation or an expression that can be heard, seen, or read. ${ }^{41}$ In addition to being tangible, a work must also have originality and not be a creation that is already in the public domain. ${ }^{42}$

The a quo boundary map is a map created by the indigenous Moi tribe that can be protected, because the drawing of the boundary map has been realized. The Map made by the Moi tribal people illustrates where they live and in general indigenous boundary maps contain general information such as boundaries, roads, connections, and other natural and cultural formations. ${ }^{43}$

The discrepancy in the registration of the document owned by the Moi tribal community is found in the issuance of the registration certificate in the form of the result of the indigenous tribe meeting. The results of a meeting are not like a boundary map that is explicitly included in a protected work in Article 40 paragraph (1) letter $\mathrm{i}$ of Law 28/2014. If examined further, there are several articles that implicitly exclude the results of the meeting as a protected creation. Article 41 of Law 28/2014 excludes several forms that are not included as creation/

\footnotetext{
${ }^{41}$ Kadek Julia Mahadewi, 'Budaya Hukum Dalam Keberlakukan Undang-Undang Nomor 28 Tahun 2014 Tentang Hak Cipta Pada Pengrajin Perak Di Bali’ (2015) 4 Jurnal Magister Hukum Udayana.[205-218].

${ }^{42}$ Tommy Hottua Marbu,[et.,al.], 'Perlindungan Hukum Hak Cipta Terhadap Karya Cipta Lagu Dan Musik Dalam Bentuk Ringtone Pada Telepon Seluler' (2013) 1 Jurnal Hukum Ekonomi Transparency.[6].

${ }^{43}$ I Ketut Sardiana and Wayan P. Windia, 'Pemetaan Partisipatif Melalui Aplikasi GPS Untuk Mitigasi Konflik Batas Wilayah: Studi Kasus Di Desa Adat Nyuh Kuning, Ubud, Bali’ (2018) 8 Jurnal Kajian Bali.[148-149].
} 
work, one of which is a procedure/system/data even though it has been disclosed, stated, explained, illustrated, or combined in a work. Moreover Article 42 of Law $28 / 2014$ emphasizes that the results of open meetings of state institutions, statutory regulations, state or government speeches, or decisions of judges are not creations protected by copyright. Thus, the results of the indigenous meeting are included in the exclusion of works that are not protected by copyright under Article 41 jo. Article 42 of Law 28/2014. The indigenous council session includes the exclusion of unprotected creations because it is classified as a result of an open meeting of state institutions in a smaller scope, where the current national law, the indigenous law community is recognized by the Indonesian constitution as regulated in Article 18B paragraph (2) of the 1945 Constitution.

\section{Legal Force of Registration od Copyright Documents as Evidence to Prove the Ownership of Indigenous Land Rights}

The issue of land ownership is not the domain of copyright protection, but inland law which constitutes a small part of agrarian law. The basis of this agrarian law is Article 33 paragraph (3) of the 1945 Constitution of the Republic of Indonesia, which states that the earth, water, and natural resources contained therein are controlled by the State and used for the greatest prosperity of the people. The phrase "used for the greatest possible prosperity of the people" is further elaborated in the implementation of the basic agrarian law, one of which is giving land ownership rights to the people of Indonesia.

According to Article 20 paragraph (1) of the agrarian law property rights are hereditary, strongest and fullest rights that a person can own on land. According to hereditary means that ownership rights to the land can be transferred because of the law from a landowner to their heir. ${ }^{44}$ The strongest means that the right to land is the strongest land right than the other land rights, do not have a period, is not easy to draw or erased, and is easily defended from interference from other

\footnotetext{
${ }^{44}$ H. A. Achmad Chomzah, Hukum Pertanahan (Prestasi Pustaka 2000).[5].
} 
parties. ${ }^{45}$ The most complete means that the right of ownership to the land gives the most extensive authority to the owner, that is, the land can be used according to the wishes of the holder of the right to the land as long as it does not violate the rights of others and the applicable laws and regulations for other land rights. ${ }^{46}$ Even though land rights are hereditary, strongest, and fullest, social functions also remain attached to land rights under Article 6 of the agrarian law The social function of ownership rights over land means that the power a person has over his property rights is also limited by the interests of the community. ${ }^{47}$ The existence of this social function is itself an implementation of the phrase "used for the greatest prosperity of the people" in Article 33 of the 1945 Constitution of the Republic of Indonesia.

The issuance of ownership rights over land is regulated in Article 22 of the UUPA (Basic Agrarian Law) governed alternatively, namely:

1. according to indigenous law governed by a Government Regulation;

2. the stipulation of the government, under the terms and manner stipulated by the Government Regulation;

3. statutory provisions.

The occurrence of property rights must be followed by having evidence to maintain ownership. The making of the evidence must go through registration. Article 23 of the UUPA (Basic Agrarian Law) also states that land rights must be registered where registration is a strong means of proof of the legality of both the imposition, transfer or removal of ownership rights over land. Thus, registered in the land book through land registration is important evidence to prove ownership.

Considering that the Moi indigenous people are Papua indigenous people, it is also necessary to look at the perspective of Law Number 21 Year 2001 regarding Special Autonomy for Papua Province and its amendments (hereinafter referred to

\footnotetext{
${ }^{45}$ Satria Braja Hariandja,[et., al.], 'Perlindungan Hukum Pemegang Hak Atas Tanah Terhadap Objek Yang Sama (Studi Putusan Nomor Putusan 55 Pdt. G. 2007/PN.RAP)’ (2019) 18 Jurnal Hukum Kaidah.

${ }^{46}$ Albert, 'Kajian Yuridis Tentang Eksistensi Hak Milik Atas Tanah Yang Belum Memiliki Sertifikat Kepemilikan Tanah’ (2016) 5 Lex Crimen.[46].

47 Triana Rejekiningsih, 'Asas Fungsi Sosial Hak Atas Tanah Pada Negara Hukum (Suatu Tinjauan Dari Teori, Yuridis, Dan Penerapannya Di Indonesia)’ (2016) 5 Yustisia.[305].
} 
as the Papua Special Autonomy Law). The Papua Special Autonomy Law regulates the protection of the rights of indigenous and tribal people, including land rights and intellectual property rights. Land rights are regulated in Article 43 of the Papua Special Autonomy Law. Article 43 Paragraph (2) of the Papua Special Autonomy Law states that the rights of indigenous peoples include the indigenous rights of indigenous peoples and the individual rights of the members of the indigenous people concerned. Article a quo shows that the indigenous rights of indigenous people in Papua, including the right of indigenous people of the Moi tribe are recognized rights. Not only indigenous rights, but intellectual property rights also get recognition and protection in Article 44 of the Papua Special Autonomy Law.

Obtaining protection through the Papua Special Autonomy Law is not enough, but the implementation of the protection of these rights is the problem. Implementation of the protection of indigenous peoples' land rights also needs to adhere to the explanation of Article 43 of the Papua Special Autonomy Law. ${ }^{48}$ The explanation of the norm in the articles of the law does not have the same binding power as the statement of the article itself..$^{49}$ However, based on Attachment I of Law Number 12 of 2011 concerning Laws and Regulations explains that the position of explanation is as an official interpretation of certain norms in the law. If an explanation of the law is used as an authentic/official interpretation, then it becomes the interpretation stated by the legislator in the law itself.49. Elucidation of Article 43 of the Papua Autonomy Law states that "consultation between the parties that require indigenous land from the indigenous law community concerned precedes the issuance of a permit to obtain and grant rights by the competent authority. Agreement on the results of the deliberation is a condition for the issuance of the permit and the decision to grant the relevant rights." Based on this explanation, the

\footnotetext{
${ }^{48}$ Iskandar Muda, 'Penafsiran Hukum Yang Membentuk Keadilan Legal Dalam Penyelesaian Sengketa Perbankan Syariah Kajian Putusan Mahkamah Konstitusi Nomor 93/PUU-X/2012’ (2016) 9 Jurnal Yudisial.[41].

49 Adi Condro Bawono, 'Fungsi Penjelasan Dan Lampiran Peraturan Perundang-Undangan' (hukumonline, 2012) <https:/www.hukumonline.com/klinik/detail/ulasan/cl6386/fungsi-dan-peran-penjelasanlampiran-suatu-peraturan-perundangundangan/> accessed 25 March 2020.
} 
legislators stated that the agreement resulting from deliberation or the approval of the indigenous authority alone was not enough to be used as a basis for the transfer of rights. Legitimate transfer of rights must, of course, be interpreted systematically under statutory regulations regarding land registration.

Even though protection and recognition of the rights of indigenous and tribal peoples have been regulated in statutory regulations, especially in the UUPA (Basic Agrarian Law) and the Special Autonomy Law in Papua, the conditional recognition continues to harm indigenous peoples. The loss can be seen from the side of the submission of indigenous law to state law known as weak legal pluralism..$^{50}$ In other words, indigenous law applies if it is recognized by the state, including in terms of proving ownership of indigenous land. The institution that registers the means of proving ownership rights over land to become legal is a government institution, namely the regional land office. Based on Article 1 number 23 of Government Regulation Number 24 of 1997 concerning Land Registration, the regional land office is a work unit of the National Land Agency in the district or municipality, which registers land rights and maintains a general register of land registrations. Thus, in a de facto way indigenous law communities exercise control over indigenous land, but by de jure, the land is owned by someone else, then this will certainly lead to conflict. This is due to the land registration system and the nature of the evidence of ownership rights to the land.

The land registration system in Indonesia is negative in the sense that the government recognizes certificates of land rights as proof of rights, as strong evidence as long as they are not proven otherwise. The statement is also explained in the Elucidation of Article 32 paragraph (2) Government Regulation Number 24 of 1997 concerning Land Registration. Based on Article 23 letter a Government Regulation Number 24 of 1997 concerning Land Registration, "land rights can be proven by:

50 Abdul Mukmin, 'Sertifikat Sebagai Alat Bukti Sempurna Kepemilikan Hak Atas Tanah Ditinjau Dari Peraturan Pemerintah Nomor 24 Tahun 1997 Tentang Pendaftaran Tanah' (2019) 1 Yuriska.[78].;Bernard Steny, 'Pluralisme Hukum: Antara Perda Pengakuan Masyarakat Adat Dan Otonomi Hukum Lokal’ (2006) 3 Jurnal Pembaruan Desa dan Agraria.[84-85]. 
a. Determination of the granting of rights from an authorized official to grant the relevant rights by the law in force if whether it grants rights originate from State land or land management rights;

b. The original PPAT deed which contains the granting of right by the holder of the ownership right to the recipient if it concerns the right to use the building and use rights on the land".

Meanwhile, the evidence of the previous right is regulated in Article 24 of Government Regulation No. 24 of 1997 concerning Land Registration. Indigenous and tribal people who do not have legal written proof from the government for their indigenous land ownership are not in an advantageous position, because they will have difficulties in proving their rights. But in truth, proof of ownership does not required to be in written form. The article 24 paragraph (2) in Government Regulation Number 24 of 1997 concerning Land Registration provides alternative evidences through other forms that can be trusted to prove the physical control of the land, such as the testimony of others. Thus, indigenous land can still be registered under the laws and regulations regarding land registration, specifically according to Government Number 24 of 1997 concerning Land Registration. The registration of indigenous land is needed to ensure legal certainty for the indigenous law community itself in accordance with Article 19 of the Basic Agrarian Law. ${ }^{51}$

Based on the explanation, the registration of a copyright certificate is not proof of ownership of land rights. If the indigenous people of Moi postulate a land as their own, then the appointment of a copyrighted document is not an object that can be submitted as evidence, other than evidence in Article 23 or Article 24 of Government Regulation Number 24 of 1997 concerning Land Registration. Document of copyright registration is not intended to show the right to own land, but as an initial allegation in copyright protection. This was also confirmed in the Letter of the Ministry of Law and Human Rights of the Republic of Indonesia Directorate General of Intellectual Property Number HKL 2-KI.01.07-05 regarding

\footnotetext{
${ }^{51}$ Indah Mahniasari, 'Pendaftaran Tanah Indegenous' (2013) 5 Al' Adl.[27-31].
} 
the explanation regarding the copyright document. The letter states that the copyright registration document is limited to works such as the boundary map itself, cannot be used as proof of ownership of the legal status of land rights.

\section{Conclusion}

The legal position of the registration of a boundary map copyright is a letter declaring the existence of a creator with a protected work. Although copyright protection starts from the time the creation was realized (first to use), the Law 28/2014 still opens the opportunity to register the work. Registration of a work/ copyright is an important act for the creator as an evidence of the initial suspicion that someone who registers the work is to be called the creator until there is another party who can prove otherwise. Unlike the registration of a boundary map under Article 40 paragraph (1) letter $\mathrm{i}$ of Law 28/2014, the recording of the results of a trial $/$ meeting assembly should not be a protected creation.

The registration of copyright is the domain of intellectual property rights related to the protection of intellectual property. Thus, the registration document does not have the legal force to prove the ownership of land, because the proof of ownership of land is a regime of land law. Evidence to prove ownership is not sourced from registration letter of copyrights, but the evidence that is regulated in UUPA (Basic Agrarian Law)and Government Regulation Number 24 of 1997 concerning Land Registration.

\section{Bibliography}

Abdul Mukmin, 'Sertifikat Sebagai Alat Bukti Sempurna Kepemilikan Hak Atas Tanah Ditinjau Dari Peraturan Pemerintah Nomor 24 Tahun 1997 Tentang Pendaftaran Tanah' (2019) 1 Yuriska.

Adi Condro Bawono, 'Fungsi Penjelasan Dan Lampiran Peraturan PerundangUndangan' (hukumonline, 2012) < https://www.hukumonline.com/klinik/ detail/ulasan/c16386/fungsi-dan-peran-penjelasanlampiran-suatu-peraturanperundangundangan/> accessed 25 March 2020.

Ahyat Ari Gayo, 'Perlindungan Hukum Ha Katas Tanah Adat (Studi Kasus Di 
Provinsi Aceh Khususnya Kabupaten Bener Meriah)' (2016) 18 Jurnal Penelitian Hukum De Jure.

Albert, 'Kajian Yuridis Tentang Eksistensi Hak Milik Atas Tanah Yang Belum Memiliki Sertifikat Kepemilikan Tanah' (2016) 5 Lex Crimen.

Andi Bustamin Daeng Kunu, 'Kedudukan Hak Ulayat Masyarakat Adat Dalam Hukum Tanah Nasional' (2010) 10 Inspirasi.

Bernard Steny, 'Pluralisme Hukum: Antara Perda Pengakuan Masyarakat Adat Dan Otonomi Hukum Lokal' (2006) 3 Jurnal Pembaruan Desa dan Agraria.

Bplawyers, 'Hak Cipta: Mengenal Lebih Dalam Hak Cipta Di Indonesia' (Bplawyers, 2018) <https://bplawyers.co.id/2018/01/30/hak-cipta-diindonesia/> accessed 26 February 2020.

Bzn. Ter Haar, Asas-Asas Dan Susunan Hukum Adat (Pradnya Parata 1999).

Dedy Miswar, Kartografi Tematik, vol Aura (Aura 2012).

Direktorat Jenderal Badan Peradilan Umum, 'Statistik Perkara Perdata Klasifikasi Objek Sengketa Tanah Tahun 2017' (Direktorat Jenderal Badan Peradilan Umum, 2017) <https://badilum.mahkamahagung.go.id/publik/statistikperkara/statistik-perkara-perdata/2512-statistik-perkara-perdata-klasifikasiobjek-sengketa-tanah-tahun-2017.html> accessed 23 March 2020.

Direktorat Jenderal Kekayaan Intelektual, 'Pangkalan Data Kekayaan Intelektual' (Direktorat Jenderal Kekayaan Intelektual, 2018) <https:// pdki-indonesia.dgip.go.id/index.php/hakcipta?type $=2 \&$ q14[from $]=01-03$ 2019\&q14[until]=23-03-2020\&filter_by=dicatat $>$ accessed 23 March 2020.

Ebta Setiawan, 'KBBI Online' $(K B B I, 2019)<$ https://kbbi.web.id/tapal-3> accessed 24 March 2020.

Eka Hindrati, 'Melawan Perampasan Wilayah Adat Dengan Peta Wilayah Adat' (aman, 2015) <http://www.aman.or.id/2019/05/melawan-perampasanwilayah-adat-dengan-peta- wilayah-adat/> accessed 26 February 2020.

Ermansyah Djaja, Hukum Hak Kekayaan Intelektual (Sinar Grafika 2009).

H. A. Achmad Chomzah, Hukum Pertanahan (Prestasi Pustaka 2000).

Hayatul Ismi, 'Pengakuan Dan Perlindungan Hukum Hak Masyarakat Adat Atas Tanah Ulayat Dalam Upaya Pembaharuan Hukum Nasional' (2012) 3 Jurnal 
Ilmu Hukum Fakultas Hukum Universitas Riau.

Henry Soelistyo, Hak Cipta Tanpa Hak Moral (Rajawali Pers 2011).

Hermanto Suaib, Nilai-Nilai Kearifan LokalDanModalSosialDalam Pemberdayaan Masyarakat Suku MOI (Penerbit Book Online 2017).

Heru Nugroho, 'Menggugat Kekuasaan Negara', Muhamadyah University Press (2001).

I Ketut Sardiana and Wayan P. Windia, 'Pemetaan Partisipatif Melalui Aplikasi GPS Untuk Mitigasi Konflik Batas Wilayah: Studi Kasus Di Desa Adat Nyuh Kuning, Ubud, Bali' (2018) 8 Jurnal Kajian Bali.

Inda Nurdahniar, 'Analisis Penerapan Prinsip Perlindungan Langsung Dalam Penyelenggaraan Pencatatan Ciptaan' (2016) 2 Veritas et Justitia.

Indah Mahniasari, 'Pendaftaran Tanah Indegenous' (2013) 5 Al' Adl.

Iskandar Muda, 'Penafsiran Hukum Yang Membentuk Keadilan Legal Dalam Penyelesaian Sengketa Perbankan Syariah Kajian Putusan Mahkamah Konstitusi Nomor 93/PUU-X/2012' (2016) 9 Jurnal Yudisial.

Iswi Hariyani, Prosedur Mengurus HKI Yang Benar (Pustaka Yustisia 2010).

Kadek Julia Mahadewi, 'Budaya Hukum Dalam Keberlakukan Undang-Undang Nomor 28 Tahun 2014 Tentang Hak Cipta Pada Pengrajin Perak Di Bali' (2015) 4 Jurnal Magister Hukum Udayana.

Maria Rosalina, 'Pengaturan Pemeriksaan Setempat (Decentee) Dalam Peraturan Perundang-Undangan Di Indonesia' (2018) 18 Jurnal Hukum Kaidah $<$ https:// jurnal.uisu.ac.id/index.php/jhk/article/view/909>.

Maria S.W. Sumardjono,[et,.al.], Kebijakan Pertanahan Antara Regulasi \& Implementasi (Kompas 2001).

Maria Sumardjono,[et.,al.], Mediasi Sengketa Tanah (Potensi Penerapan Alternatif), Penyelesaian Sengketa Di Bidang Pertanahan) (Kompas Media 2008).

Mochamad Adib Zain and Ahmad Siddiq, 'Pengakuan Atas Kedudukan Dan Keberadaan Masyarakat Hukum Adat (MHA) Pasca Dibentuknya UndangUndang Nomor 6 Tahun 2014 Tentang Desa' (2015) 2 Jurnal Penelitian Hukum.

Nelwan Ronsumbre and Mohammad Benny, 'Keberadaan Perwakilan Wilayah Adat 
Di Dewan Perwakilan Rakyat Papua (DPRP) Dalam Perspektif Representasi Di Provinsi Papua' (2018) 1 Responsive.

Peter Mahmud Marzuki, Penelitian Hukum (Prenada Media Group 2005).

Rosalina, 'Eksistensi Hak Ulayat Di Indonesia’ (2010) 16 Jurnal Sasi.

Satria Braja Hariandja,[et.,al.] 'Perlindungan Hukum Pemegang Hak Atas Tanah Terhadap Objek Yang Sama (Studi Putusan Nomor Putusan 55 Pdt. G. 2007/ PN.RAP)' (2019) 18 Jurnal Hukum Kaidah.

Siti Hatikasari, 'Esensi Perlindungan Hukum Dalam Sistem First to Announce Atas Karya Cipta’ (2018) 27 Supremasi Hukum: Jurnal Penelitian Hukum.

Sthephen M. McJohn, Copyright, Examples \& Explanation (Aspen Publisher 2006).

Sudjana, 'Sistem Perlindungan Atas Ciptaan Berdasarkan Undang-Undang Nomor 28 Tahun 2014 Tentang Hak Cipta Dalam Perspektif Cyber Law' (2016) 2 Veritas et Justitia.

Sufiarina, 'Hak Prioritas Dan Hak Ekslusif Dalam Perlindungan HKI' (2013) 3 ADIL:Jurnal Hukum.

Titik Triwulan Tutik, 'Hakikat Keilmuan Ilmu Hukum Ditinjau Dari Sudut Filsafat Ilmu Dan Teori Hukum' (2012) 24 Mimbar Hukum.

Tommy Hottua Marbu,[et.,al.] 'Perlindungan Hukum Hak Cipta Terhadap Karya Cipta Lagu Dan Musik Dalam Bentuk Ringtone Pada Telepon Seluler' (2013) 1 Jurnal Hukum Ekonomi Transparency.

Tomy Suryo Utama, Hak Kekayaan Intelektual (HKI) Di Era Global (Graha Ilmu 2010).

Triana Rejekiningsih, 'Asas Fungsi Sosial Hak Atas Tanah Pada Negara Hukum (Suatu Tinjauan Dari Teori, Yuridis, Dan Penerapannya Di Indonesia)' (2016) 5 Yustisia.

Trias Palupi Kurnianingrum, 'Materi Baru Dalam Undang-Undang Nomor 28 Tahun 2014 Tentang Hak Cipta' (2015) 6 Jurnal Negara Hukum.

Urip Santoso, 'Kewenangan Pemerintah Daerah Dalam Penguasaan Atas Tanah' (2013) 27 Jurnal Mimbar Hukum.

Xavier Nugraha,[et.,al.], 'Rekonstruksi Batas Usia Minimal PerkawinanSebagai Bentuk Perlindungan Hukum TerhadapPerempuan' (2019) 3 Lex Scentia. 
Yulianan A and Heriyanti, 'Model Partisipasi Masyarakat Moi Dalam Pelaksanaan Pendidikan Adat Kambik (Studi Kasus Tentang Kelangsungan Pendidikan Kambik Di Suku Moi Kampung Maladofok Kabupaten Sorong)' (2019) 4 Jurnal Noken.

HOW TO CITE: Christina Ella Yonatan and Xavier Nugraha, 'Analysis on the Legal Force of Copyright Registration Document as Evidence of Ownership of Indigenous Land' (2021) 36 Yuridika. 